\title{
Modeling Amoxicillin Removal From Aquatic Environments in Biofilters
}

\author{
Mohammad Ali Baghapour ${ }^{1, ;}$; Mohammad Reza Shirdarreh '; Zahra Derakhshan ${ }^{2}$; \\ Mohammad Faramarzian ${ }^{2}$ \\ ${ }^{1}$ Department of Environmental Health Engineering, School of Health, Shiraz University of Medical Sciences, Shiraz, IR Iran \\ ${ }^{2}$ Student Research Committee, Department of Environmental Health Engineering, School of Health, Shiraz University of Medical Sciences, Shiraz, IR Iran \\ ${ }^{*}$ Corresponding author: Mohammad Ali Baghapour, Department of Environmental Health Engineering, School of Health, Shiraz University of Medical Sciences, Shiraz, IR Iran. Tel: \\ +98-7117251001, Fax: +98-7117260225, E-mail: baghapour@sums.ac.ir
}

Received: August 6, 2013; Revised: September 7, 2013; Accepted: September 8, 2013

\begin{abstract}
Background: Modeling aims at simulation or optimization of a process in various environments and is an essential tool that allows researchers to gain a better understanding of processes.Also, modeling helps to predict the scientific events. In spite of the great advantages of antibiotics, these compounds enter into the environments through various pathways, changeand destroy differentecosystems, andlead to bacterial resistance. Amoxicillin is widely used as an antibiotic in modern medicine. Due to its certain physicochemical characteristics, it leaks into aquatic environments. Up to now, many physical and chemical methods have been recommended for removing amoxicillin from soil and aquatic environments. However, these methods are very costly.

Objectives: The present study aimed to evaluate and model the capability of the biological aerated filters (BAFs) in degradation of amoxicillin from aquatic environments in different concentration levels of amoxicillin and hydraulic retention times (HRTs).

Materials and Methods: In this study, biodegradation of amoxicillin by BAF was evaluated in the aquatic environment. In order to assess amoxicillin removal from the aquatic environment, this bioreactor was fed with synthetic wastewater at four amoxicillin concentration levels and three HRTs.

Results: The results showed that maximum amoxicillin and chemical oxygen demand(COD) removals by aerated biofilter were $50.7 \%$ and $45.7 \%$, respectively.

Conclusions: The study results showed that Stover-Kincannon model had a great fitness $\left(\mathrm{R}^{2}>99 \%\right)$ for loading this biofilter with amoxicillin.
\end{abstract}

Keywords: Amoxicillin; Anti-Bacterial Agents; Biodegradation, Environmental; Waste Water

\section{Background}

Groundwater contamination by pharmaceutical compounds (PhCs) is one of the major environmental concerns $(1,2)$. Nowadays, nearly 3000 PhCs with natural origins and synthetic metabolites are used all over the world $(3,4)$. These compounds as environmentally hazardous materials are able to change various ecosystems (5). Due to insufficient treatments and waste disposals, the PhCs have also been identified in surface water, groundwater, and water and wastewater treatment plants (6-8). The sources of PhCs in nature might include domestic, hospital, and industrial wastewater and effluents from farming activities as well as pharmaceutical industries' wastes ( 9 , 10). These PhCs are increasingly used for prophylaxis and treatment of diseases (11). Antibiotics are among the PhCs with natural, synthetic, and semi-synthetic origin which have anti-microbial properties (12). These compounds have been widely produced since the second World War (13). Amoxicillin is one of the most widely used antibiotics. It belongs to the penicillin family and beta-lactam category and is produced semi-synthetically. This drug is among the broad-spectrum antibiotics and affects a large number of gram positive and gram negative microorganisms. In addition, due to proper oral absorption, it is more widely used in comparison to the other members of the penicillin family $(12,14,15)$. Some of the physicochemical properties of amoxicillin include, molecular weight of $365.40 \mathrm{~g} / \mathrm{mol}$, pKa (acid dissociation constants) of 9.41 and Log KOW (octanol/water partition coefficient) of $0.87(16,17)$. Due to its chemical structure, consumption rate, solubility, pharmacological characteristics and

Implication for health policy/practice/research/medical education:

Modeling aims to simulate or optimize a process in physical, chemical or biological environments. In case the obtained model has desirable fitness, it will be of great help in producing data and predicting the unknown conditions. Nowadays, modeling is increasingly used in science. In spite of the great advantages of antibiotics, these compounds enter the environments through various processes, change and destroy different ecosystems and lead to bacterial resistance. Up to now, many physical and chemical methods have been recommended for removing amoxicillin from soil and aquatic environments. However, these methods are very costly. Hence, biological aerated filter (BAF) can play a critical role in reducing the treatment costs through its treatment mechanisms.

Copyright @ 2014, Health Promotion Research Center. This is an open-access article distributed under the terms of the Creative Commons Attribution License, which permits unrestricted use, distribution, and reproduction in any medium, provided the original work is properly cited. 
environmental toxicity, amoxicillin is considered as one of the primary contaminants, which should too slightly exist in aquatic environments $(10,18,19)$. Nevertheless, because of the insufficient treatments of amoxicillin in conventional water and wastewater treatment methods, this compound enters both into the surface and groundwater and destroys the aquatic ecosystems. It also leads to bacterial resistance and consequently the inability to treat diseases using conventional antibiotics (20-22). Therefore removing amoxicillin from the environment is a major problem.

Most bacteria, such as Escherichia coli (23), Staphylococcus aureus (24), Helicobacter pylori (25) and Acinetobacter (26) have shown bacterial resistance to antibiotics. Jelic et al. (2012) (11) investigated the effect of different factors on the efficiency of treatment of wastewaters bearing PhCs. The study showed that when hydraulic retention times (HRT) increased, pharmaceuticals removal significantly increased. Gartiser et al. (2007) (27) reviewed the inherent biodegradability of 17 antibiotics in a combined test design based on the Zahn-Wellens test. According to the results, only amoxicillin, imipenem and nystatin showed certain ultimate biodegradation. Amoxicillin degradation by microorganisms, such as Microcystisaeruginosa (28) and Rhodococcus B30 (9) has been proved by previous researches. For better understanding, the results of some researches performed on microbial degradation of amoxicillin are summarized in Table 1.

\section{Objectives}

Considering the fact that groundwater resources are increasingly being used for supplying drinking water and reports have been presented regarding bacterial resistance to most antibiotics, researches have to be conducted on the treatment and removal of these dangerous materials from the environment. Thus, the present study aimed to remove various concentrations of amoxicillin from aquatic environment and consequently, reduced its emission in the environment. Also, this study aimed to be modeled in order to predict its fate in the biological aerated filter (BAF) and obtain the parameters of designing this biofilter.

\section{Materials and Methods}

\subsection{Chemicals}

All chemicals used in this study were purchased from Merck Co. (Germany) with greater than 98\% purity. Amoxicillin standard was supplied by Sigma Aldrich (The USA), dichloromethane as solvent (99.5\% purity) and deionized water (Millipore Milli-Q) were used in this study. The stock solution was prepared by dissolving the required amounts of chemicals in deionized water. Except for amoxicillin, all stock solutions were autoclaved at $120{ }^{\circ} \mathrm{C}$ for 20 minutes and then kept at $4{ }^{\circ} \mathrm{C}$. In order to prevent precipitation, the stock solutions were kept separately and were not mixed with each other. Amoxicillin solution was prepared (strength $0.01 \mathrm{mg} / \mathrm{L}$ to $10.0 \mathrm{mg} / \mathrm{L}$ ) by dissolving a known quantity of amoxicillin in distilled water followed by intermittent shaking for at least five days. Cartridge amoxicillin solution was covered with the aluminum foil and kept at $4{ }^{\circ} \mathrm{C}$ in the dark in order to prevent photolytic degradation.

\subsection{Reactor Setup}

As Figure 1 shows, the experimental reactor was made of a BAF whose physical characteristics are presented in Table 2.

Table 1. The Results of Previous Studies on Amoxicillin Removal

\begin{tabular}{lll}
\hline Operational Condition & HRT $^{\mathrm{a}}, \mathbf{h}$ & $\begin{array}{l}\mathbf{A M X}^{\mathrm{a}} \text { Removal } \\
\text { Efficiency }\end{array}$ \\
\hline $\begin{array}{l}\text { Up-flow anaerobic sludge } \\
\text { blanket (UASB) }\end{array}$ & 23.2 & $21.6(15)$ \\
\hline $\begin{array}{l}\text { Up-flow anaerobic sludge } \\
\text { blanket (UASB) }\end{array}$ & 23.5 & $20.2(29)$ \\
$\begin{array}{l}\text { Novel micro-aerobic hydrolysis } \\
\text { acidification reactor(NHAR) }\end{array}$ & 9.3 & $20.4(29)$ \\
\hline
\end{tabular}

a Abbreviations: AMX, amoxicillin; HRT, hydraulic retention times.

Figure 1. Schematic Image of Physical Mode

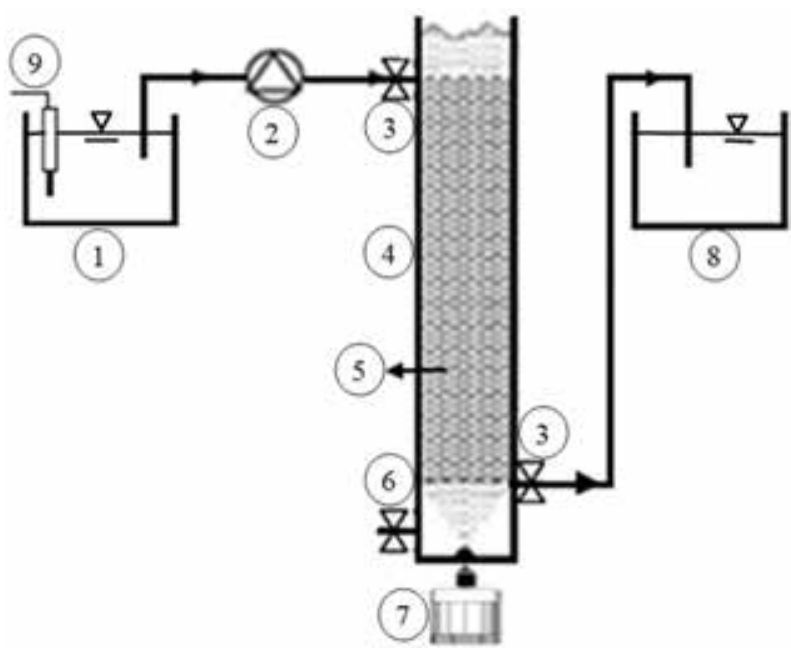

1) Reservoir of feed stock, 2) Peristaltic pump, 3) Sampling ports, 4) Biological aerated filter, 5) Packing media, 6) Discharge sludge port, 7) Air compressor, 8) Reservoir of outlet, 9) Temperature controller. 
The media used in the current study was made of highdensity polyethylene pieces whose properties are shown in Table 3.

The biological filter was filled with the prepared media up to $55 \mathrm{~cm}$. Then, this area was separated from the up-sidedown diffusers using a mesh plate made of Plexiglas. Overall, four diffusers were used in this filter. The free board intended for the bioreactor was $5 \mathrm{~cm}$. In addition, a discharge valve placed $2 \mathrm{~cm}$ from the bioreactor floor was used for probable discharge of the excess sludge. Then, the filter effective volume was computed using the porosity and phasic relations obtained from porosity test. In order to prevent the interference effect of light (photocatalyst) and algae growth, the external wall of the reactor was covered by aluminum foil. In addition, a control pilot with the same physical features of the pilot was utilized in order to increase the accuracy and eliminate the effect of the interfering factors. Aeration was done from the bottom of the BAF reactor using diffusers. Besides, the amount of the injected air was chosen in a way that oxygen would not be a limiting factor for the biological growth.

\subsection{Synthetic Wastewater}

The synthetic wastewater used for feeding the bioreactor was based on sucrose and tap water with COD of 1000 $\pm 21.6 \mathrm{mg} / \mathrm{L} ; \mathrm{pH}$ fluctuations were controlled using 0.5 $\mathrm{mol} / \mathrm{L}$ sodium bicarbonate. Table 4 shows the composi- tion of wastewater used as the feed of the pilot reactor during the test period.

Synthetic wastewater was injected to the top of the aerobic filter by a peristaltic pump. Based on the study by Zhou et al. (30) the maximum removal efficiency of biodegradation of PhCs occurs at $32{ }^{\circ} \mathrm{C}$. Accordingly, in this study the temperature in the reservoir was controlled at $32 \pm 0.2^{\circ} \mathrm{C}$ using an electric heater.

\subsection{Startup and System Operation}

The column was filled with $10000 \mathrm{mg} / \mathrm{L}$ of synthetic wastewater. In addition, seeding was provided by aerobic bacteria collected from an activated sludge system treating the pharmaceutical industry effluent (Ahura Daru Co.). Total solids (TS) concentration of the seed sludge was approximately $100 \mathrm{~g} / \mathrm{L}, 95 \%$ of which was total volatile solids (TVS). The air compressor was then turned on and the reactors started to work in a batch condition. In aerobic conditions, the mixed bacteria are stimulated to grow by adding oxygen, and start producing enzymes, which can oxidize or degrade the target pollutant. The sludge was fed with wastewater for a month to make the system adapted to the changed environment and was used for further experiments. During this period, very low concentrations of amoxicillin were added for further acclimatization of the microorganisms with the operational conditions.

Table 2. Physical Properties of the Reactor

\begin{tabular}{llllll}
\hline Column & Outside Diameter, $\mathbf{m m}$ & Inside Diameter, $\mathbf{m m}$ & Height, $\mathbf{c m}$ & $\mathbf{V}_{\mathrm{t}}^{\mathrm{a}}, \mathbf{L}$ & $\mathbf{V}_{\mathrm{e}}^{\mathrm{a}}, \mathbf{L}$ \\
Biological aerated filter & 110 & 100 & 60 & 4.7 & 3.9 \\
\hline
\end{tabular}

a Abbreviations: $\mathrm{V}_{\mathrm{e}}$, effective volume; $\mathrm{v}_{\mathrm{t}}$, total volume.

Table 3. Physical Properties of the Media

\begin{tabular}{ll}
\hline Properties & Value and Specification \\
\hline Media type & Fixed bed (random packed) \\
\hline Shape & Corrugated Raschig rings \\
\hline Material & HDPE ${ }^{\text {a }}$ \\
\hline Density, Mean $\pm \mathbf{S D}, \mathbf{k g} / \mathbf{m} 3$ & $186 \pm 2$ \\
\hline Specific gravity & 0.98 \\
\hline Porosity, \% & 92 \\
\hline Specific area, $\mathbf{m} 2 / \mathbf{m} 3$ & 410 \\
\hline Thickness, $\mu \mathrm{m}$ & 350 \\
\hline Outside diameter, $\mathbf{m m}$ & 15 \\
\hline Inside diameter, $\mathbf{m m}$ & 12 \\
\hline Height, mm & $11-13$ \\
\hline
\end{tabular}

a Abbreviations: HDPE, high density polyethylene.
Table 4. Chemical Composition of Synthetic Wastewater

\begin{tabular}{|c|c|}
\hline Component & Concentration, mg/L \\
\hline \multicolumn{2}{|l|}{ Nutrients } \\
\hline $\mathrm{NaHCO}_{3}$ & 20 \\
\hline $\mathrm{MgSO}_{4} \cdot 7 \mathrm{H}_{2} \mathrm{O}$ & 5 \\
\hline $\mathrm{KH}_{2} \mathrm{PO}_{4}$ & 5 \\
\hline $\mathrm{CaCl}_{2} \cdot 2 \mathrm{H}_{2} \mathrm{O}$ & 5 \\
\hline $\mathrm{FeSO}_{4} \cdot 7 \mathrm{H}_{2} \mathrm{O}$ & 0.2 \\
\hline $\mathrm{ZnCl}_{2}$ & 0.1 \\
\hline $\mathrm{CoCl}_{2}$ & 0.1 \\
\hline $\mathrm{NiCl} 2$ & 0.1 \\
\hline $\mathrm{CuSO}_{4} \cdot 5 \mathrm{H}_{2} \mathrm{O}$ & 0.001 \\
\hline $\mathrm{H}_{3} \mathrm{BO}_{3}$ & 0.01 \\
\hline $\mathrm{MnSO}_{4}$ & 0.5 \\
\hline$(\mathrm{NH} 4)_{2} \mathrm{HP}_{2} \mathrm{O}_{4}$ & 50 \\
\hline $\mathrm{C1}_{2} \mathbf{H}_{22} \mathbf{O}_{11}$ & Variable (600-900) \\
\hline \multicolumn{2}{|l|}{ Amoxicillin } \\
\hline Variable & $0.01,0.1,1$ and 10 \\
\hline
\end{tabular}


The bacterial adaptation stage lasted for about 25 days. During this time, the wastewater inside the reactors was changed 4 times and $\mathrm{pH}, \mathrm{DO}$, and temperature were measured as $7.3 \pm 0.2,4.3 \mathrm{mg} / \mathrm{L}$ and $32 \pm 0.2{ }^{\circ} \mathrm{C}$, respectively. The reduction of soluble chemical oxygen demand (SCOD) was also measured daily. To ensure the microbial activity during this stage, surface cultivation of mixed liquor suspended solids (MLSS) and bioflims in the bioreactor was frequently done in a mineral salts medium (MSM) solution containing amoxicillin. The MSM preparation method was performed based on the study by Rezaee et al. (31).Since the amoxicillin concentration in the environment depends on various factors and conditions, in order to investigate a wide range of concentrations, logarithmic concentrations of 0.01, 0.1, 1 and 10 $\mathrm{mg} / \mathrm{L}$ were selected and amoxicillin removal efficiency of the system was determined. Sampling was regularly carried out in duplicates and when the column reached a steady state regarding the amoxicillin residuals and soluble COD, the efficiency of amoxicillin and SCOD removal was determined.

Amoxicillin was measured by a high performance liquid chromatograph (HPLC) (Model: UV-2487, Water, the USA) using UV/VIS detector at a wavelength of $230 \mathrm{~nm}$ and using Dionex Summit P580, HPLC pump. Analysis was carried out according to the method reported by Zazouli et al. (32) and the analytes were filtered using a $0.22 \mu \mathrm{m}$ nylon syringe filter (Albert). The concentration of amoxicillin was determined using a reversed phase C18 column, $0.5 \mu \mathrm{m}, 4.6 \times 250 \mathrm{~mm}$ (Spherisorb®, Water, the USA). The injection volume was $20 \mu \mathrm{L}$, the column working at room temperature, the mobile phase was acetate ammonium $(0.01 \mathrm{~mol} / \mathrm{L})$ and acetonitrile $(\mathrm{ACN})$ was delivered at a constant flow rate of $0.5 \mathrm{~mL} / \mathrm{min}$, and the peak retention time was 12 minutes. Before each run, the instruments were standardized with the anticipated amoxicillin concentration range. For standardization of the instrument, six amoxicillin standards were prepared in advance and stored in an amber bottle in the refrigerator at $4{ }^{\circ} \mathrm{C}$ until use. The standards were prepared by serial dilutions. To check the amoxicillin build-up in the biofilm and sludge, the method suggested by Matsuo et al. (33) was utilized. The COD was assessed using a termoreactor (AQUALYTIC) and spectrophotometer (DR5000). In addition, $\mathrm{pH}$ was computed using a $\mathrm{pH}$ meter (Ohmmeter). Finally, DO was assessed by a DO meter (HACH) and room temperature was measured through a mercury thermometer. The sampling method and the experiments unless otherwise specified the analyses of various parameters were done according to procedures suggested by standard methods for the examination of water and wastewater (34). In order to assess the effect of HRT on the efficiency of the filter, wastewater with strength of $1000 \pm 21.6 \mathrm{mg} / \mathrm{L}$ was injected to the aerobic reactor by a peristaltic pump with different amoxicillin concentrations and various discharges corresponding to different HRTs and different volumetric organic loads (VOLs) in the filter. The operational scheme of the system for the 12 phases (runs) is presented in Table 5.

\section{Results}

In this study, HRT of 24 hours followed by HRTs of 12 and 6 hours were evaluated. Accordingly, the reactor flow rates were $0.1504,0.3009$, and $0.6018 \mathrm{~L} / \mathrm{h}$, respectively. The most important parameters assessed in the present study were SCOD and amoxicillin concentrations. In order to summarize and more clearly state the results, the biofilter effluent SCOD and amoxicillin in various HRTs are presented in Table 6 and 7.

\begin{tabular}{|c|c|c|c|c|c|}
\hline Run & $\begin{array}{l}\text { Hydraulic Retention } \\
\text { Times, h }\end{array}$ & $\begin{array}{l}\text { Initial Concentration of } \\
\text { Amoxicillin, } \mathrm{mg} / \mathrm{L}\end{array}$ & $\begin{array}{l}\text { Initial Concentration of } \\
\text { SCOD }{ }^{\mathrm{a}} \text {, Mean } \pm \text { SD, } \mathrm{mg} / \mathrm{L}\end{array}$ & $\mathrm{DO}^{\mathrm{a}}$, Mean $\pm S D, \mathrm{mg} / \mathrm{L}$ & pH \\
\hline $\mathbf{1}$ & 24 & 0.01 & $992 \pm 19.70$ & $4.3 \pm 0.38$ & 7.32 \\
\hline 2 & 24 & 0.1 & $996 \pm 12.71$ & $4.4 \pm 0.44$ & 7.38 \\
\hline 3 & 24 & 1 & $994 \pm 12.30$ & $4.3 \pm 0.36$ & 7.30 \\
\hline 4 & 24 & 10 & $995 \pm 12.61$ & $4.5 \pm 0.40$ & 7.39 \\
\hline 5 & 12 & 0.01 & $998 \pm 10.45$ & $4.5 \pm 0.37$ & 7.32 \\
\hline 6 & 12 & 0.1 & $998 \pm 15.05$ & $4.4 \pm 0.39$ & 7.44 \\
\hline 7 & 12 & 1 & $1005 \pm 5.62$ & $4.3 \pm 0.40$ & 7.34 \\
\hline 8 & 12 & 10 & $998 \pm 8.14$ & $4.4 \pm 0.34$ & 7.33 \\
\hline 9 & 6 & 0.01 & $1010 \pm 14.31$ & $4.5 \pm 0.37$ & 7.24 \\
\hline 10 & 6 & 0.1 & $1004 \pm 14.19$ & $4.4 \pm 0.41$ & 7.33 \\
\hline 11 & 6 & 1 & $1001 \pm 9.35$ & $4.3 \pm 0.39$ & 7.29 \\
\hline 12 & 6 & 10 & $991 \pm 8.66$ & $4.3 \pm 0.40$ & 7.40 \\
\hline
\end{tabular}




\subsection{Modeling}

One of the best criteria for designing and utilizing biofilters for water and wastewater treatment is the VOL and the rate of substrate removal is obtained from the following equations $(35,36)$ (Equation 1 and 2 ):

Equation 1. $B_{\mathrm{AMX}}=\frac{Q}{V} C_{i}$

Equation 2. $r_{\mathrm{AMX}}=\frac{Q}{V}\left(C_{i}-C_{e}\right)$

Where BAMX is the amoxicillin load per unit volume of the filter (kgAMX/m3d); rAMX is the volumetric amoxicillin removal ( $\mathrm{kgAMX} / \mathrm{m} 3 \mathrm{~d})$; $\mathrm{Ci}$ is amoxicillin concentration in the influent $(\operatorname{kgAMX} / \mathrm{m} 3)$; Ce is amoxi- cillin concentration in the effluent $(\operatorname{kgAMX} / \mathrm{m} 3)$; $\mathrm{Q}$ is inflow rate to the reactor $(\mathrm{m} 3 / \mathrm{d})$; $\mathrm{V}$ is reactor volume (m3). Using Equation 1 and 2 together with Table 5, 6 and 7, values of BAMX and rAMX could be computed for various situations. The main values are presented in Table 8.

In order to establish a relationship between the filter volumetric loading and the bioreactor efficiency in amoxicillin and SCOD removal, among non-linear StoverKincannon, logistic, Harris, and Exponential Association models, the best one with the highest fitness was selected via an univariate analysis using the Curve Expert software. The results are presented in Table 9. Amoxicillin and organic loading of the bioreactor with the StoverKincannon model have been shown in Figure 2 and 3.

Table 6. Amoxicillin Removal Efficiency

\begin{tabular}{lllll}
\hline \multirow{2}{*}{ Hydraulic Retention Times, $\mathbf{h}$} & \multicolumn{4}{c}{ Initial Amoxicillin Concentration, $\mathbf{m g} / \mathbf{L}, \%$} \\
\cline { 2 - 5 } & $\mathbf{0 . 0 1}$ & $\mathbf{0 . 1}$ & $\mathbf{1}$ & $\mathbf{1 0}$ \\
\hline $\mathbf{6}$ & 11.2 & 20 & 23.1 & 29.3 \\
$\mathbf{1 2}$ & 18.6 & 22.4 & 30.3 & 36.6 \\
$\mathbf{2 4}$ & 25.8 & 30.5 & 40.2 & 50.7 \\
\hline
\end{tabular}

Table 7. Soluble Chemical Oxygen Demand Removal Efficiency

\begin{tabular}{lllll}
\hline \multirow{2}{*}{ Hydraulic Retention Times, $\mathbf{h}$} & \multicolumn{4}{c}{ Initial Amoxicillin Concentration, $\mathbf{m g} / \mathbf{L}, \%$} \\
\cline { 2 - 5 } & $\mathbf{0 . 0 1}$ & $\mathbf{0 . 1}$ & $\mathbf{1}$ & $\mathbf{1 0}$ \\
\hline $\mathbf{6}$ & 31.0 & 30.1 & 27.3 & 31.3 \\
$\mathbf{1 2}$ & 40.1 & 38.4 & 38.6 & 39.2 \\
$\mathbf{2 4}$ & 44.3 & 43.1 & 41.7 & 45.7 \\
\hline
\end{tabular}

Table 8. Volumetric Load and Removal of Amoxicillin and SCOD From the Bioreactor at $32{ }^{\circ} \mathrm{C}$

\begin{tabular}{lllll}
\hline $\mathbf{R u n}$ & $\mathbf{B}_{\mathrm{AMX}}\left(\mathbf{k g}_{\mathrm{AMX}} / \mathbf{m}^{3} \mathbf{d}\right)$ & $\mathbf{r}_{\mathrm{AMX}}\left(\mathbf{k g}_{\mathrm{AMX}} / \mathbf{m}^{3} \mathbf{d}\right)$ & $\mathbf{B S C O D}\left(\mathbf{k g}_{\mathrm{SCOD}} / \mathbf{m}^{3} \mathbf{d}\right)$ & $\mathbf{r}_{\mathrm{SCOD}}\left(\mathbf{k g}_{\mathrm{SCOD}} / \mathbf{m}^{3} \mathbf{d}\right)$ \\
\hline $\mathbf{1}$ & $1.84 \times 10_{-5}$ & $5.765 \times 10-6$ & 1.84 & 1.2581 \\
$\mathbf{2}$ & $1.84 \times 10_{-4}$ & $5.648 \times 10-5$ & 1.84 & 1.2211 \\
$\mathbf{3}$ & $1.84 \times 10-3$ & $1.968 \times 10-4$ & 1.84 & 1.2468 \\
$\mathbf{4}$ & $1.84 \times 10-2$ & $5.347 \times 10-3$ & 1.84 & 1.2055 \\
$\mathbf{5}$ & $3.68 \times 10-5$ & $6.881 \times 10-6$ & 3.68 & 2.3766 \\
$\mathbf{6}$ & $3.68 \times 10-4$ & $8.316 \times 10-5$ & 3.68 & 2.4766 \\
$\mathbf{7}$ & $3.68 \times 10-3$ & $1.119 \times 10-3$ & 3.68 & 2.4060 \\
$\mathbf{8}$ & $3.68 \times 10-2$ & $1.133 \times 10-2$ & 3.68 & 2.5091 \\
$\mathbf{9}$ & $7.36 \times 10-5$ & $8.243 \times 10-6$ & 7.36 & 4.8060 \\
$\mathbf{1 0}$ & $7.36 \times 10-4$ & $1.472 \times 10-4$ & 7.36 & 4.8099 \\
$\mathbf{1 1}$ & $7.36 \times 10-3$ & $2.002 \times 10-3$ & 7.36 & 4.8792 \\
$\mathbf{1 2}$ & $7.36 \times 10-2$ & $2.156 \times 10-2$ & 7.36 & 4.8043 \\
\hline
\end{tabular}


Baghapour MA et al.

\begin{tabular}{|c|c|c|c|c|}
\hline Model & Equation Structure & Equation Coefficient & Coefficient Values & $\mathbf{R}^{2}$ \\
\hline \multirow[t]{2}{*}{ Stover-Kincannon } & $r_{\mathrm{AMX}}=a \frac{B_{\mathrm{AMX}}}{b+B_{\mathrm{AMX}}}$ & $\mathrm{a}$ & 20.6 & 0.999 \\
\hline & & $\mathrm{b}$ & 20.58 & \\
\hline \multirow[t]{3}{*}{ Exponential association } & $r_{\mathrm{AMX}}=\mathrm{a}\left(\mathrm{b}-\mathrm{e}^{-\mathrm{cB}} \mathrm{AMX}\right)$ & a & -20.89 & 0.993 \\
\hline & & $\mathrm{b}$ & 0.988 & \\
\hline & & c & -0.184 & \\
\hline \multirow[t]{3}{*}{ Logistic } & $r_{\mathrm{AMX}}=\frac{a}{(1+\mathrm{be})}-c B_{\mathrm{AMX}}$ & a & 4.81 & 0.991 \\
\hline & & $\mathrm{b}$ & 9.46 & \\
\hline & & c & 60.51 & \\
\hline \multirow[t]{3}{*}{ Harris } & $r_{\mathrm{AMX}}=\frac{1}{\left(\mathrm{a}+\mathrm{bB}_{\mathrm{AMX}^{\mathrm{c}}}\right)}$ & a & 10.05 & 0.988 \\
\hline & & $\mathrm{b}$ & -9.67 & \\
\hline & & c & 0.0293 & \\
\hline
\end{tabular}

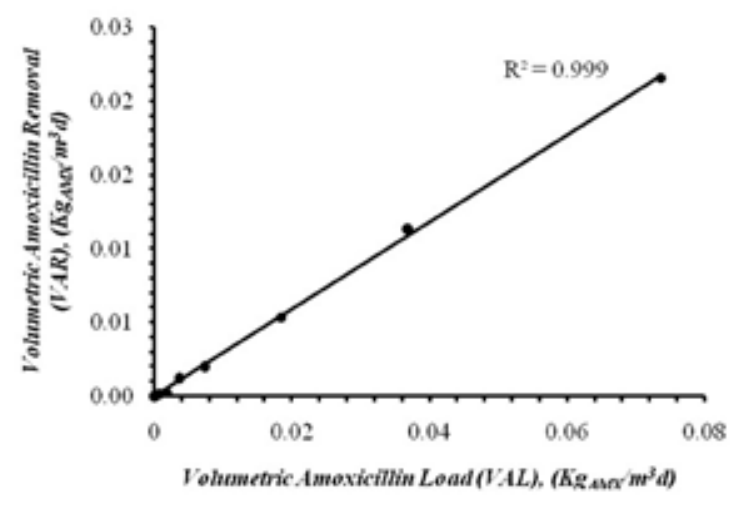

Figure 2. Amoxicillin Loading of the Bioreactor in the Range of $0-0.08$ $\mathrm{kg}_{\mathrm{AMX}} / \mathrm{m}^{3} \mathrm{~d}$ at $32{ }^{\circ} \mathrm{C}$

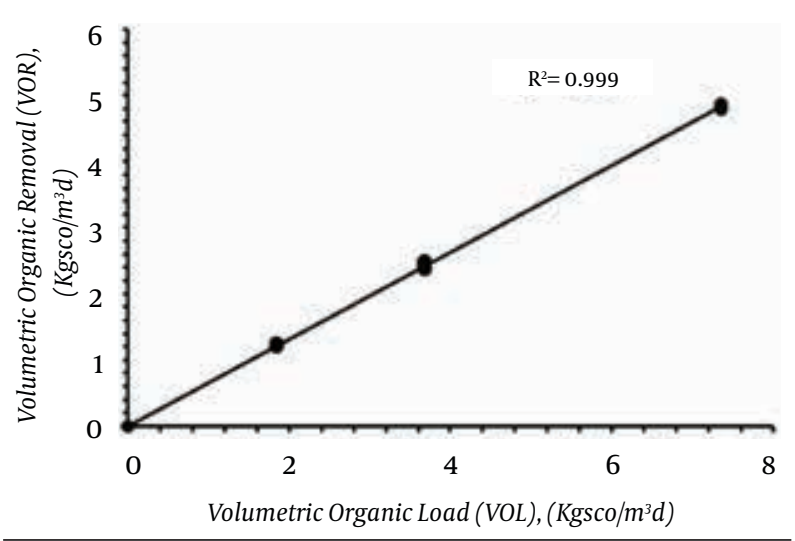

Figure 3. Organic Loading of the Bioreactor in the Range of $0-8 \mathrm{~kg}_{\mathrm{SCOD}}$ $\mathrm{m}^{3} \mathrm{~d}$ at $32{ }^{\circ} \mathrm{C}$

\section{Discussion}

According to the results, as the HRT increased, the bioreactor reached a steady state more quickly. This is in agreement with the findings of the Baghapour et al. study (37) on the performance of submerged aerated filters in wastewater treatment and biological excess sludge production. Considering the high proportion of attached growth to suspended microbial growth and reaching appropriate efficiency, there was no need for sludge return to the system. This is one of the great advantages of this treatment method indicating the media capability as well as reduction of pumping costs. Submerged aerated filter showed high efficiency in removing organic matters and stable toxic materials. In this study, in spite of using an inexpensive media, the mean amoxicillin and SCOD removal was desirable for all the study stages. As Table 6 depicts, the highest rates of amoxicillin removal were related to $10,1,0.1$ and $0.01 \mathrm{mg} / \mathrm{L}$ concentrations with the efficiencies of $50.7 \%, 40.2 \%, 30.5 \%$ and $25.8 \%$, respectively. The findings of this study demonstrated that the solution containing amoxicillin was biodegraded and treated in a submerged biological aerated filter. Moreover, amoxicillin removal efficiency was more than 35\% where high amoxicillin influent was introduced in the BAF (runs 3, 4 and 8). The treatment efficiencies achieved at longer HRT (12 hours) in the BAF fed with low, moderate, and high amoxicillin concentrations in the influent are summarized in Table 6. It is evident that in comparison with other HRTs, amoxicillin and SCOD removal efficiencies were increased at long HRT due to the slight decrease in amoxicillin and organic loading rates in the BAF. However, the extent of amoxicillin loading rate was not highly 
effective on biological amoxicillin and organic removal efficiencies. Thus, it can be concluded that amoxicillin degradation depends on the rate of organic matter in the aquatic environment as well as the influent amoxicillin concentration. Measurement of COD is important regarding the effluent discharge standards and COD represents the treatment potential of the reactor. In this study, BAF showed acceptable SCOD removal efficiency in all experiments. Besides, amoxicillin had no adverse effects on SCOD removal up to the concentration of 10 $\mathrm{mg} / \mathrm{L}$. However, SCOD reduction was decreased by $2 \%$ - $4 \%$ when amoxicillin concentration was increased to 0.1 and $1 \mathrm{mg} / \mathrm{L}$. The comparison of the previous (Table 1 ) and the present studies results showed that this system has high ability for removing amoxicillin from aqueous solutions. The highest rate of amoxicillin degradation compared to its highest initial concentration might be due to the effect of the concentration gradient. In high concentration gradient, the contaminants have more opportunities to be exposed to and penetrate into the cells which are an essential stage for biodegradation. There was no accumulation of amoxicillin in the biofilm and the loss of amoxicillin in the control reactor was negligible. This implies that amoxicillin removal in this system was caused by the microorganism's activity. Co-metabolic process is used for bioremediation of the most persistent contaminants, such as amoxicillin. In co-metabolic processes, by utilizing primary carbon source or nitrogen source, microbes produce enzymes or cofactors during microbial activities, which are responsible for degradation of the secondary substrates (amoxicillin). Also, the contaminants degrade in this process in order to trace concentrations. The results obtained from BAF showed that the co-metabolic process was quite effective in removing amoxicillin from the aqueous environments. Overall, the findings of the current study showed that after complete acclimatization of the microbial population, amoxicillin had no preventive effects on the microbial degradation process. Moreover, Stover-Kincannon model showed a desirable fitness in the loading process of the submerged aerated filter in amoxicillin removal in porous environments $\left(R^{2}>0.99\right)$, which is in line with the study by Coskun et al. (38).

\section{Acknowledgements}

The present article was adopted from Mohammad Faramarzian's MSc thesis in Environmental Health Engineering (grant No. 91-6164). Special thanks to the Research Improvement Center of Shiraz University of Medical Sciences, Shiraz, Iran. We would also appreciate Ms Keivanshekouh for improving the use of English in the manuscript.

\section{Authors' Contribution}

The overall implementation of this study including de- sign, experiments and data analysis as well as manuscript preparation were the results of group efforts by individuals who are listed as coauthors of this paper. All authors have made extensive contribution into the review and finalization of this manuscript.

\section{Financial Disclosure}

There are no conflicts of interest.

\section{Funding/Support}

The project was financially supported by the Research Deputy of Shiraz University of Medical Sciences, Shiraz, Iran.

\section{References}

1. Barceló D, Petrovic M, Radjenovic J. Treating emerging contaminants (pharmaceuticals) in wastewater and drinking water treatment plants. Tech Perspect fReg. 2009.

2. Daughton CG, Ternes TA. Pharmaceuticals and personal care products in the environment: agents of subtle change? Environ Health Perspect. 1999;107 Suppl 6:907-38.

3. Al Aukidy M, Verlicchi P, Jelic A, Petrovic M, Barcelo D. Monitoring release of pharmaceutical compounds: occurrence and environmental risk assessment of two WWTP effluents and their receiving bodies in the Po Valley, Italy. Sci Total Environ. 2012;438:15-25.

4. Ghauch A, Tuqan A, Assi HA. Antibiotic removal from water: elimination of amoxicillin and ampicillin by microscale and nanoscale iron particles. Environ Pollut. 2009;157(5):1626-35.

5. Al-Hashimi MAI, Al-Ali MI, Abbas AH. Anaerobic treatment of pharmaceutical wastewater using packed bed reactor .J Environ Stud. 2011;7:33-40.

6. Adams C, Wang Y, Loftin K, Meyer M. Removal of antibiotics from surface and distilled water in conventional water treatment processes. J Env Eng. 2002;128(3):253-60.

7. Batt AL, Bruce IB, Aga DS. Evaluating the vulnerability of surface waters to antibiotic contamination from varying wastewater treatment plant discharges. Environ Pollut. 2006;142(2):295-302.

8. Kim SD, Cho J, Kim IS, Vanderford BJ, Snyder SA. Occurrence and removal of pharmaceuticals and endocrine disruptors in South Korean surface, drinking, and waste waters. Water Res. 2007;41(5):1013-21.

9. Githinji LJM, Musey MK, Ankumah RO. Evaluation of the fate of ciprofloxacin and amoxicillin in domestic wastewater. Water Air Soil Pollut. 2011;219(1-4):191-201.

10. Homem V, Santos L. Degradation and removal methods of antibiotics from aqueous matrices-a review. J Environ Manage. 2011;92(10):2304-47.

11. Jelić A, Gros M, Petrović M, Ginebreda A, Barceló D. Occurrence and elimination of pharmaceuticals during conventional wastewater treatment. In: Guasch H, Ginebreda A, Geiszinger A editors. Emerging and priority pollutants in rivers. Springer Berlin Heidelberg; 2012. p. 1-23.

12. Ball P. The clinical development and launch of amoxicillin/clavulanate for the treatment of a range of community-acquired infections. Int J Antimicrob Agents. 2007;30 Suppl 2:S113-7.

13. Gholami M, Mirzaei R, Kalantary RR, Sabzali A, Gatei F. Performance evaluation of reverse osmosis technology for selected antibiotics removal from synthetic pharmaceutical wastewater. Iranian J Environ Health Sci Eng. 2012;9(1):19.

14. Angadi SC, Manjeshwar LS, Aminabhavi TM. Novel composite blend microbeads of sodium alginate coated with chitosan for controlled release of amoxicillin. Int J Biol Macromol. 2012;51(12):45-55.

15. Chen Z, Wang H, Chen Z, Ren N, Wang A, Shi Y, et al. Performance and model of a full-scale up-flow anaerobic sludge blanket 
(UASB) to treat the pharmaceutical wastewater containing 6-APA and amoxicillin.J Hazard Mater. 2011;185(2-3):905-13.

16. Carless JE. Remington's pharmaceutical sciences. J Pharm Pharmacol.1966;18(7):479-80.

17. Windholz M, Budavari S, Stroumtsos LY, Fertig MN. The Merck index. An encyclopedia of chemicals and drugs. Merck \& Co.; 1976.

18. De Gusseme B, Vanhaecke L, Verstraete W, Boon N. Degradation of acetaminophen by Delftia tsuruhatensis and Pseudomonas aeruginosa in a membrane bioreactor. Water Res. 2011;45(4):182937.

19. Fent K, Weston AA, Caminada D. Ecotoxicology of human pharmaceuticals. Aquat Toxicol. 2006;76(2):122-59.

20. Elmolla ES, Chaudhuri M. Improvement of biodegradability of synthetic amoxicillin wastewater by photo-Fenton process. World Appl Sci J. 2009;5:53-58.

21. Ding R, Zhang P, Seredych M, Bandosz TJ. Removal of antibiotics from water using sewage sludge- and waste oil sludge-derived adsorbents. Water Res. 2012;46(13):4081-90.

22. Fatta D, Achilleos A, Nikolaou A, Meric S. Analytical methods for tracing pharmaceutical residues in water and wastewater. $\operatorname{Tr} A C$ Trend Anal Chem. 2007;26(6):515-33.

23. Brinas L, Zarazaga M, Saenz Y, Ruiz-Larrea F, Torres C. Beta-lactamases in ampicillin-resistant Escherichia coli isolates from foods, humans, and healthy animals. Antimicrob Agents Chemother. 2002;46(10):3156-63.

24. Jury KL, Vancov T, Stuetz RM, Khan SJ. Antibiotic resistance dis semination and sewage treatment plants. Curr Res Tech Educ Top Appl Microbiol Microb Biotechnol. 2010:509-19.

25. Qureshi NN, Morikis D, Schiller NL. Contribution of specific amino acid changes in penicillin binding protein 1 to amoxicillin resistance in clinical Helicobacter pylori isolates. Antimicrob Agents Chemother. 2011;55(1):101-9.

26. Zhang Y, Marrs CF, Simon C, Xi C. Wastewater treatment contributes to selective increase of antibiotic resistance among Acinetobacter spp. Sci Total Environ. 2009;407(12):3702-6.

27. Gartiser S, Urich E, Alexy R, Kummerer K. Ultimate biodegradation and elimination of antibiotics in inherent tests. Chemosphere. 2007;67(3):604-13.

28. Liu Y, Guan Y, Gao B, Yue Q. Antioxidant responses and degrada- tion of two antibiotic contaminants in Microcystis aeruginosa. Ecotoxicol Environ Saf. 2012;86:23-30

29. Chen Z, Wang H, Ren N, Cui M, Nie S, Hu D. Simultaneous removal and evaluation of organic substrates and NH3-N by a novel combined process in treating chemical synthesis-based pharmaceutical wastewater. J Hazard Mater. 2011;197:49-59.

30. Zhou P, Su C, Li B, Qian Y. Treatment of High-Strength Pharmaceutical Wastewater and Removal of Antibiotics in Anaerobic and Aerobic Biological Treatment Processes. J Environmen Eng. 2006;132(1):129-36.

31. Rezaee D, Haghnia GH, Lakzian A. [Biodegradation of atrazine in different concentrations by Pseudomonas bacteria]. J Plant Protect . 2011;25(2):223-6.

32. Zazouli M, Ulbricht M, Nasseri S, Susanto H. Effect of hydrophilic and hydrophobic organic matter on amoxicillin and cephalexin residuals rejection from water by nanofiltration. Iran J Environ Health Sci Eng. 2010;7(1).

33. Matsuo H, Sakamoto H, Arizono K, Shinohara R. Behavior of pharmaceuticals in waste water treatment plant in Japan. Bull Environ Contam Toxicol. 2011;87(1):31-5.

34. Clesceri LS, Eaton AD, Greenberg AE, American Public Health Association, American Water Works Association, Water Environment Federation. Standard Methods for the Examination of Water and Wastewater. Washington DC: American Public Health Association; 1998.

35. Baghapour MA, Jabbari I. [Performance of submerged aerated biofilters for wastewater treatment and excess biological sludge production]. Water Wastewater. 2007;64:2-14.

36. Baghapour M, Nasseri S, Derakhshan Z. Atrazine removal from aqueous solutions using submerged biological aerated filter. $J$ Env Health Sci Eng. 2013;11(1):6.

37. Baghapour M, Jabbari E, Baskaran K. Reducing of excess sludge production in wastewater treatment using combined anaerobic/aerobic submerged biological filters. Iran J Env Health Sci Eng. 2011;8(3).

38. Coskun T, Kabuk HA, Varinca KB, Debik E, Durak I, Kavurt C. Antibiotic Fermentation Broth Treatment by a pilot upflow anaerobic sludge bed reactor and kinetic modeling. Bioresour Technol. 2012;121:31-5. 